\title{
THE POETICS OF THE NOVELLA IN CORRELATION TO VASYL STEFANYK'S ARTISTIC VISION
}

\author{
STEPAN KHOROB
}

\begin{abstract}
The article discusses correlations between artistic vision and poetics in Vasyl Stefanyk's novellas. It is argued that the writer's modernist aesthetic experience left its imprint on his literary works. The author concludes that the writer's artistic vision followed a dynamic course of development correlating with the poetics of the novella and enriching the stylistic color scheme of his narrative prose.
\end{abstract}

Keywords: artistic vision, context, poetics, the novella, tradition and novelty.

\section{INTRODUCTION}

The poetics of Vasyl Stefanyk's narrative prose has so widely been discussed in research papers on literary criticism that it will take several volumes to publish them. In fact, an analysis of his novellas alone unfolds a whole range of permanent concepts such as "artistry", "a system of creative principles", "literary form", "coherence", "the writer's craft", etc., which do not manifest themselves fully or equally at all levels. On the contrary, numerous studies have explored the above-mentioned concepts from different perspectives. In fact, their correlation depends primarily on the conceptual framework for analyzing the poetics of the entire oeuvre, or a single literary work, or some of its external and internal constituents and so on; and the concept per se depends on the variability of its structure, which makes poetics always open for identifying new themes, expanding the ones already found, rethinking certain methods and methodological experiences [1].

Thus the poetics of Vasyl Stefanyk's novellas remains a topical issue despite numerous research findings $[2 ; 12 ; 13 ; 14 ; 18]$. We would like to focus on a little-researched aspect, namely the founding principles of the writer's artistic vision, which left an imprint on his conceptual framework and writing style, as well as on the correlations between his poetic devices, etc. As a matter of fact, Vasyl Stefanyk belongs to the generation of writers who lived at the turn of the $20^{\text {th }}$ century and who managed to abandon kitchen-sink ethnography, thus raising Ukrainian literature to the highest standards of excellence that existed at the time. This superb master has created a novel type of flash fiction - laconic but capable of giving a profound social and psychological analysis of reality. Literary critics have rightly attributed the intrinsic ethnic significance of Vasyl Stefanyk's literary works to the novelty of their genre, which manifests itself in its similarity to the novella, a lapidary plot, dramatism and lyricism, the musicality and plasticity of narration. Describing the originality of Stefanyk's artistic 
vision, many researchers who were excessively focused on socialist methodology used to regard him as an adept of "critical realism", thus totally neglecting the writer's modernist aesthetic experience [3].

Therefore, as the title of the paper suggests, it would be relevant to note that the impressionism of Vasyl Stefanyk's flash fiction as a type of modernist artistic vision was largely fueled by the novel atmosphere of the literary epoch, the one created by the leaders of Young Poland - Stanisław Przybyszewski, Jan Kasprowicz, Stanisław Wyspiański, Kazimierz Przerwa-Tetmajer, Władysław Orkan, whom the writer met at Jagiellonian University and knew well. Obviously, it was there in Krakow that Vasyl Stefanyk not only made his first attempts at gaining an understanding of Polish modernism, but also created impressionistic images, which vividly expressed his perception of the surrounding world and his characters' attitudes. It was also there in Krakow that Vasyl Stefanyk wrote many other works of flash fiction marked by modernism [4].

To date, there is an obvious need for a comprehensive account of the founding principles of the writer's artistic vision in general, as well as of the synthesizing relationship between realist and modernist artistic practices. It is for this reason that any claims about the influence of Young Poland on the writer's consciousness, particularly during the Krakow period of his literary career, must be regarded with some reservations. Firstly, as rightly noted by E. Wiśniewska, the poetic and dramatic works of the representatives of Young Poland tended towards symbolism or, in rare cases, towards expressionism rather than impressionism [5]. Secondly, as argued by I. Denysiuk, I. Moskovina, R. Pikhmanets, and N. Shumylo, the nature of the subjective in Vasyl Stefanyk's narrative vision is so prominent and overwhelming that it characterizes the impressionistic concentration on the aloofness and tragedy of an individual who is faced with the hostility and disharmony of the surrounding world, "depicted with the help of the poetics of moral shock" [6].

\section{ANALYSIS AND Discussion}

Thus further studies on Vasyl Stefanyk's oeuvre must be intended to supply an obvious need for a comprehensive and multi-faceted account of the poetics of his flash fiction, primarily that of the novella, which exhibits originality not only in terms of genre or narrative framework but also the selfsufficiency and intrinsic value of the writer's aesthetic experience. In fact, this will contribute to a more profound understanding of the subjective transformative basis of the writer's novellas. The structure of V. Stefanyk's novellas (as well as his narrative prose as a whole) must be explored from several, or at least two, perspectives: an extensive study of the "micropoetics" of the writer's works, as well as the "macropoetics" of his artistic vision, its coherent system of imagery and stylistic approaches [7; 10]. This approach seems to have great research potential, if only because it allows for the possibility of identifying V.Stefanyk's narrative oeuvre as a complete phenomenal metatext which reflects his infinitely unique poetics, thematic preoccupations and aesthetic experience and has yet to be extensively researched by Ukraine's literary critics [8].

In this regard, it should be noted that at the turn of the $20^{\text {th }}$ century writers displayed a tendency towards cyclization (of a literary movement, a literary society, or a writer's oeuvre), which became particularly prominent in the novella. To illustrate, let us consider V. Stefanyk's novellas. The abovementioned tendency can be seen even in his first collection of novellas entitled Synya knyzhechka (The Blue Book), where the plots of Vyvodyly z sela (The Village Send-Off) and Stratyvsya (The Suicide) intertwine. The two novellas are centered around the anguish of parents whose son was unable to endure the regimented routine of military service and thus committed suicide. Despite the fact that the characters of the novellas U korchmi (In the Tavern) and Leseva familiya (Les' Family) have different names and are faced with different life circumstances and psychological problems, the two storylines are so intertwined that they seem to reflect two stages of a person's destiny: first the character tries to drink

\footnotetext{
* Here and henceforth, the titles of V.Stefanyk's novellas are given as translated by Joseph Wiznuk, in collaboration with C. H. Andrusyshen (The stone cross [by] Vasyl Stefanyk. Translated from the Ukrainian by Joseph Wiznuk, in collaboration with C. H. Andrusyshen. Toronto, 1971).
} 
his sorrow away, and then he gets beaten by his wife and children for drinking the last of their money away.

The plots of the other novellas in Synya knyzhechka are also interwoven, which is why researchers stress that the book is not merely a collection of narrative works sharing a resemblance in theme and form, but specific narrative cycles where all the novellas are deeply intertwined and complement each other, thus creating a unique thematic and aesthetic superunity [9; 18]. Literary historians have observed that at the turn of the $20^{\text {th }}$ century such collections of works, particularly those of narrative prose, came to be referred to as books. V. Stefanyk's books are further interconnected to form a larger whole, a certain metatext, which reflects the writer's vision of the world and human existence [10], characterizes the poetics of his novellas and his artistic vision.

V. Stefanyk's first and second collections of novellas, which are structured as metatexts, are generally perceived as complete and coherent due to sharing a set of clear-cut narrative storylines, characters, spatio-temporal setting, and imagery. Needless to say, they are combined and represented differently in every novella. As a matter of fact, such combinations are regarded as structural elements and are materialized by the author throughout his entire oeuvre. Here are the most common narrative storylines: a person leaving their home or native village (Vyvodyly z Sela [The Village Send-Off], Kaminnyi khrest [The Stone Cross], Vona - Zemlya [She - the Earth], Ditocha pryhoda [Children's Adventure], etc.); old and helpless people awaiting death in dreadful loneliness (Anhel [The Angel], Sama-samiska [All Alone], Shkoda [The Loss], Portret [The Portrait], Svyatyi vechir [Christmas Eve], Skin [The Agony], Ozymyna [Winter Crop], etc.); parents anguished by their children's sudden death (Stratyvsya [The Suicide], Lan [The Potato Field], Syny [The Sons], Pokhoron [The Funeral], Mariya, Katrusya, etc.). These narrative storylines can be synthesized to give a philosophical account of an individual and their destiny, or human existence in general. "The mythologically happy past of ancestors, the unbearably agonizing present, and no future other than death - such are the temporal coordinates of the fictional world in Synya knyzhechka (The Blue Book), which reflect the basis of V. Stefanyk's worldview as a whole. This spatio-temporal context gave rise to a framework for portraying a peasant as a representative of the human kind and social collisions as fragments of his or her existence" [10].

In this regard, it should be noted that in Stefanyk's novellas, tragic feelings and concepts such as death preserve their national connotations (obviously, due to the influence of Ukrainian folklore), but they are perceived as universally significant. In addition, the writer's narrative manner and narrative structure also exhibit folkloric elements. According to I. Denysiuk's insightful observations, works of literary art as an independent and coherent aesthetic phenomenon synthesize the characteristics of the stream-of-consciousness novella and lament [8]. Stefanyk's narrative prose, however, does not exhibit the characteristics of the novella in its traditional interpretation. I. Kachurovskyi is convinced that Novyna (The News) is a representative example of the antinovella: from its very beginning on, the reader's interest in the unusual, the exceptional (father drowns his daughter) is gradually overshadowed by their desire to find out about the reasons (social, mental, familial) for the horrible act committed by Hryts Letiuchyi. The rest of the writer's novellas do not contain anything unpredictable such as an unexpected twist in the plot (pointe), with Basaraby (The Basarabs) being the only exception [11].

In other words, most of Stefanyk's works are not marked by traditional plot twists, which are characteristic of the novella. Despite this, there is an atmosphere of unexpectedness in his narrative storylines; however, it is deeply embedded in narrative structure. Unexpectedness "arises the moment the writer shifts perspectives on village life - from social realism to moral psychology, or even moral philosophy, at both universal and culture-specific levels. This turning point in the composition of the narrative urges the reader to rethink the events portrayed, to view them from an entirely new, hitherto unknown angle" [12]. As regards the external structure of the writer's works, it bears a certain resemblance to that of the short story, whose generic structural feature is a monologue or a dialogue.

Research on the "micropoetics" of Stefanyk's novellas and the "macropoetics" of his narrative prose, as well as intratextual links between discrete works and the continuity of plot allows for a more profound understanding of the writer's artistic vision in correlation to the poetics of his novellas. His 
images of the world and an individual are polysemous. Though they are associated with a certain social and historical context, it does not dominate in the thematic and aesthetic structure of his narratives. Moreover, it is regarded as a secondary element of narrative structure because Stefanyk attaches greater importance to viewing his characters and storylines from universal and culture-specific perspectives. Researchers (Danylo Husar-Struk, Dmytro Kozii, Luka Lutsiv, and Yulian Vassyian, among others) note that the characters in Stefanyk's novellas used to be elevated to the status of supertypes comparable with similar characters in international works of literature at the turn of the $20^{\text {th }}$ century. This characteristic of Stefanyk's writing manner was noted by the writer's contemporary literary critics. At present, however, considering the wealth of knowledge amassed about the epoch in question, it is possible to give a more profound analysis of a whole range of Stefanyk's novellas. One thing that clearly stands out is that most of his characters do not exhibit any unique traits because, in fact, their psychological perceptions of reality and their lives were not particularly different. It seems that in the centre of Stefanyk's fictional universe there is one character at different stages of their life. His novellas, as stressed above, are interwoven into a single organic and coherent spectacle - lyrical, dramatic, narrative, expressive [10].

To illustrate, the characters of Stefanyk's novellas give the impression of being one big family (Father, Mother, Son, Daughter, Sister, Brother, Grandfather, Grandmother, their numerous fellow villagers) bound not only by kin but also by spiritual (Christian) human ties. The plotlines reflect stages in human life: birth (Klenovi lystky [The Maple Leaves], Pistunka [A Baby-Sitter], etc.), childhood (Mamyn synok [Mommy's Boy], Katrusya, Osin [Autumn], Novyna [The News], Lan [The Potato Field], Ditocha pryhoda [Children's Adventure], etc.), wedding (Sud [The Judgement]), conscription (Vyvodyly z Sela [The Village Send-Off]), exhausting labor (most novellas), lonely oldhood (Anhel [The Angel], Sama-samiska [All Alone], Shkoda [The Loss], Portret [The Portrait], Svyatyi vechir [Christmas Eve], Skin [The Agony], etc.). All these novellas portray people who are faced with the tragedy of death, which is grotesquely intertwined with birth: a woman dies in childbirth (Klenovi lystky [The Maple Leaves]) or her child is in danger of dying (Pistunka [A Baby-Sitter]). Tragedy is unavoidable even on happy occasions such as a Christmas celebration (Svyatyi vechir [Christmas Eve], Lyst [The Letter]) or a wedding, like in Sud (The Judgement) since the event was marred by a lynching. In general, death stalks children and young people (Pokhoron [The Funeral], Katrusya, Ditocha pryhoda [Children's Adventure]), and especially elderly people anguished by life's difficulties.

It should be stressed that the conflict portrayed in Stefanyk's novellas stems not from social antagonism or, more specifically, not so much from external contradicting forces as from an internal, psychological, urge against injustice; as a result, the characters are doomed to a never-ending struggle against death. "If the narrative storyline portrays an external conflict, the opposing parties do not normally exhibit any class distinctions. For instance, such is the clash between two poor men (Zlodiy [The Thief]) or between impoverished peasants and their better-off neighbors (Sud [The Judgement]). Such conflicts are perceived from the perspective of moral philosophy: as far as morality goes, revenge is condemned even by those who seek it [14].

Stefanyk's other works, for instance the ones portraying the characters' stream of consciousness, are also based on moral and psychological conflicts, which develop beyond social context. The characters usually think in terms of moral categories such as conscience, love, sin, and so on; they regard God, Christ, and the Mother of Jesus as models of moral integrity. Such a representation of psychological conflict indicates not only changes or, more specifically, certain transformations of Stefanyk's artistic vision [6; 13]. As a matter of fact, it also puts a construction on those modifications of conflict as an aesthetic category during the literary epoch under discussion: conflict was not so much described as was reflected in the characters' consciousness. It is this type of conflict that serves as a basis of Stefanyk's narrative prose. The writer places his characters in situations where they have to wonder about their destiny. Despite the routineness and mundaneness of the storylines (seemingly reminiscent of the antinovella), his characters, hanging between life and death, always choose to confront death in order to remain alive [14]. 
Ideologically unbiased resident and emigrant Ukrainian scholars of Stefanyk stressed the polysemy and magnitude of the writer's fictional universe in the system of his thematic preoccupations and aesthetic experience. Needless to say, fictional universe reflects the historical context of what is portrayed; however, Stefanyk pushes it to the background since his primary concern is a tragedy of the human soul. He amplifies the tragedy to such a degree that it not only produces a striking effect on the reader but also captures not only the social aspects of human anguish but also those lying outside the sphere of interaction - disharmony, cruelty, absurdity [15].

In fact, in a tragic and absurd world a person is doomed to react paradoxically: in an attempt to relieve their children's sufferings, parents end up wishing them death (Novyna [The News], Osin [Autumn], Katrusya); trying to escape death from starvation, children beat their father bloody (Leseva familiya [Les' Family]) or abandon their helpless old parents to their fate (Sama-samiska [All Alone]); a miserable poor man has to kill another one, thus amplifying universal grief and despondency (Zlodiy [The Thief], Mariya). In his narrative prose, Stefanyk gives a historically accurate depiction of social reality and creates a phantasmagoria of horror around the depths and ontologies of human existence.

Additionally, such perception is enhanced when the writer fits his portrayed image of the world into a broader, more embracing narrative canvas which reflects the world of Nature and Space. It is no accident that literary critics rightly noted that the vision of the World Order portrayed in Stefanyk's novellas has the same system of coordinates as the ones in folklore and religious philosophy - its axes are occupied by intrinsically opposite images - God and Devil, heaven and hell. However, in contrast to tradition, in the spirit of the decadent and symbolist literature of the time, Stefanyk's prose frequently portrays God the Son and God the Father as cruel, intensifying human suffering [13; 16]. In fact, the characters' attempts to escape the vicious circle of earthbound anguish either outside their home or village (Synya knyzhechka [The Blue Book], Novyna [The News], Vona - Zemlya [She - the Earth]), or outside their hometown (Stratyvsya [The Suicide]), or in a foreign land (Kaminnyi khrest [The Stone Cross]) are to no avail because there is only one way-out - death. This is the reason why death is regarded as liberation: Ой синку, я так тої смерті, як мами рідної, чекаю. Вночі то в кождий кут пролуплюю очі, uุи де з кута не привидитьси...(Oh, dear son, I'm anticipating that death as if it was my dear mother. At night I stare into every corner waiting for it to appear ...). However, earthbound existence is unbearable not only for humans but all living beings (Shkoda [The Loss], Kaminnyi khrest [The Stone Cross]), which is why the earth can no longer bear so much misfortune and the end of the world is about to come, so there will be nobody there. Stefanyk's characters usually resign to it, but there are also those who oppose it, for instance Les (Leseva familiya [Les' Family]), Ivan (Klenovi lystky [The Maple Leaves]), Maksym (Syny [The Sons)]. First, old Maksym even blasphemes: Господи, брешуть золоті книги - по цеерквах, щзо ти мав сина, брешуть, що-с миав! (God, in churches the golden books lie that you had a son; they lie you really did!). Eventually, he resorts to cursing: Най тобі оиял синя баня так потріскає, як моє серцее... (May this bluе dome of yours get cracked just like my heart did...) [17].

These, as well as many other Stefanyk novellas, are based on a conflict between Man and God, which was characteristic of decadent literature. However, in contrast to the latter, Stefanyk's characters and the writer himself do not abandon faith in supra-human values [18; 20] such as Love and Beauty embodied in the Mother of God. It is love and sacrifice that elevate a common human to the heights of God: those killed by their own kith and kin during a war are equaled to God; and their mother, to the Mother of God. Such is motherly love in Paliy (The Arsonist), Katrusya, Klenovi lystky (The Maple Leaves), Ditocha pryhoda (Children's Adventure), etc., and this makes Stefanyk's conception of a human being significantly different from that of the decadents.

It should be noted in this regard that there is much in common between Stefanyk's narrative prose and decadent literature of the time, even more than has been discussed in a number of research papers. Thus we need hardly adhere to the position of the modern scholar who claims that the tragedy of Vasyl Stefanyk's novellas stems from a certain situation, not from the character's doom and fatality of their existence [19]. It might seem that the novella writer, following in the decadents' footsteps, emphasizes a person's helplessness in the face of fate since every person has their own "stone cross" to bear and every person is subconsciously capable of provoking an act of cruelty or bloodshed (Sud [The 
Judgement], Zlodiy [The Thief], Paliy [The Arsonist]), as well as other immoral or, if you will, antichristian actions. "Despite all that, as well as the anti-aesthetic portrayal of most of his characters - oldsters with their heads shaking, hands trembling, lips twitching (Portret [The Portrait]), blue with cold, in the midst of rags, pounding their heads against the wall (Svyatyi vechir [Christmas Eve]), and children swollen with starvation, looking like corpses (Osin [Autumn], Novyna [The News], Klenovi lystky [The Maple Leaves], etc.), his characters, in contrast to those of decadent writers, evoke no disgust, but rather a heart-rending pity, compassion and, if you will, indignation at the global order [10].

\section{CONCLUSIONS}

This paper has examined the poetics of Vasyl Stefanyk's novella, and the findings suggest a number of conclusions. The writer perfected the structure of the novella by nurturing the Ukrainian and international literary traditions of the turn of the $20^{\text {th }}$ century, which was marked by the development of modernism. Alongside realism, he drew on modernist types of aesthetic experience, namely symbolism, impressionism, and expressionism; his narrative storylines were based on grotesque, contrast, symbols, stream of consciousness, lament. With their help, the novella writer managed to capture the absurdity of life as seen by both an individual and humanity treading the edge of a precipice. Vasyl Stefanyk combined modernist artistic experience with national folkloric and literary traditions. As a result, he invented original literary forms, which synthesized the stream-ofconsciousness novella with the lament, prayer, tragedy, realistic psychological short story. In other words, the novella writer's artistic vision resulted from his synthesized aesthetic experience, and that left an imprint on the poetics of his works. This paper has argued that the disharmony and stereoscopism of Vasyl Stefanyk's fictional universe is rooted in his perception of the world, which, as the findings show, turns out to be much more complex and tragic than commonly claimed.

\section{REFERENCES}

[1] Кодак М.П. Авторська свідомість і класична поетика. НЦ “Фоліант”, К., 2006. [Kodak M.P. Avtorska svidomist i klasychna poetyka. NTs "Foliant", K., 2006.]

[2] Лесин В.М. Василь Стефаник - майстер новели. Рад. письм., К.,1970. [Lesyn V.M. Vasyl Stefanyk - maister novely. Rad. pysm., K.,1970.]

[3] Гнідан О. Василь Стефаник. Життя і твориість. Рад.шк., К., 1991. [Hnidan O. Vasyl Stefanyk. Zhyttia i tvorchist. Rad.shk., K., 1991.]

[4] Поліщук Я. Краків як текст та естетична школа Василя Стефаника. В: Шевченко. Франко. Стефаник: Матеріахи Міжнародної наукової конференції. Плай, Івано-Франківськ, 2002, 286-296.

[Polishchuk Ya. Krakiv yak tekst ta estetychna shkola Vasylia Stefanyka. In: Shevchenko. Franko. Stefanyk: Materialy Mizhnarodnoi naukovoi konferentsii. Plai, Ivano-Frankivsk, 2002, 286-296.]

[5] Wiśnewska E. Wasyl Stefanyk w środowisku literackim Krakowa. In: Z dziejów stosunków literackich polsko-ukrainskich. Wroclaw-Warszawa-Kraków- Cdaǹsk, 1974, 75-98.

[6] Козій Д. Аюдина в межових ситуаціях (поетика творчості Василя Стефаника) В: Козій Д. Глибинний етос: Нариси з літератури і філософії. Торонто-Сідней, 1984, 67-82.

[Kozii D. Liudyna v mezhovykh sytuatsiiakh (poetyka tvorchosti Vasylia Stefanyka) In: Kozii D. Hlybynnyi etos: Narysy z literatury i filosofii. Toronto-Sidnei, 1984, 67-82.]

[7] Піхманець Р. Художньо-психологічні механізми виникнення естетичної реакції в творах Василя Стефаника. В: Шевченко. Франко. Стефаник: Матеріахи Міжнародної наукової конференції. Плай, Івано-Франківськ, 2002, 432-448.

[Pikhmanets R. Khudozhno-psykholohichni mekhanizmy vynyknennia estetychnoi reaktsii v tvorakh Vasylia Stefanyka. In: Shevchenko. Franko. Stefanyk: Materialy Mizhnarodnoi naukovoi konferentsii. Plai, Ivano-Frankivsk, 2002, 432-448.] 
[8] Денисюк I. Жанрові проблеми новелістики. В: Розвиток жанрів в украйнській літературі ХІХпочатку ХХ ст. Наук. Думка, К., 1986.

[Denysiuk I. Zhanrovi problemy novelistyky. In: Rozvytok zhanriv v ukrainskii literaturi XIX -pochatku XX st. Nauk. Dumka, K., 1986.]

[9] Денисюк I. Розвиток української малої прози кінця XIX- поч. XX cm. “Академічний експрес", Аьвів, 1999.

[Denysiuk I. Rozvytok ukrainskoi maloi prozy kintsia XIX - poch. XX st. "Akademichnyi ekspres", Lviv, 1999.]

[10] Московкіна I. Поетика Василя Стефаника. В: Збірник Харківського історико-філологічного товариства: Нова серія, Т.2. Око, Харків, 1994, 75-86.

[Moskovkina I. Poetyka Vasylia Stefanyka. In: Zbirnyk Kharkivskoho istoryko-filolohichnoho tovarystva: Nova seriia, T.2. Oko, Kharkiv, 1994, 75-86.]

[11] Качуровський I. Новела як жанр. Буенос Айрес, 1958.

[Kachurovskyi I. Novela yak zhanr. Buenos Aires, 1958.]

[12] Вассиян Ю. Мистець із землі зроджений. В: Твори, Т.2. Видання Організації Українок Канади «Евшан зілдя», Торонто, 1974.

[Vassyian Yu. Mystets iz zemli zrodzhenyi. In: Tvory, T.2. Vydannia Orhanizatsii Ukrainok Kanady «Ievshan zillia», Toronto, 1974.]

[13] Грещук В.В., Кононенко В.І., Хороб. С.І. (Ред.) Василь Стефаник - художник слова. Плай, ІваноФранківськ, 1996.

[Hreshchuk V.V., Kononenko V.I., Khorob. S.I. (Red.) Vasyl Stefanyk - khudozhnyk slova. Plai, IvanoFrankivsk, 1996.]

[14] Луців Д. Василь Стефаник - співець украйнської землі. Свобода, Ню-Йорк-Джерзі Ситі, 1971.

[Lutsiv L. Vasyl Stefanyk - spivets ukrainskoi zemli. Svoboda, Niu-York-Dzherzi Syti, 1971.]

[15] Іванишин П. Основні аспекти національно-духовної диференціації (На матеріалі прозового дискурсу В. Стефаника). В: «Покутська трійцяя й хітературний процес в Україні кінця ХІХ початку XX століть: Матеріахи наукової конференції. Вимір, Дрогобич, 2001, 126-150.

[Ivanyshyn P. Osnovni aspekty natsionalno-dukhovnoi dyferentsiatsii (Na materiali prozovoho dyskursu V. Stefanyka). In: «Pokutska triitsia» y literaturnyi protses v Ukraini kintsia XIX - pochatku XX stolit: Materialy naukovoi konferentsii. Vymir, Drohobych, 2001, 126-150.]

[16] Гаморак Ю. Василь Стефаник (Спроба біографії). В: Гаморак Ю. (Ред.) Василь Стефаник. Твори. Українське слово, Регенсбург, 1948.

[Hamorak Yu. Vasyl Stefanyk (Sproba biohrafii). In: Hamorak Yu. (Red.) Vasyl Stefanyk. Tvory. Ukrainske slovo, Regensburg, 1948.]

[17] Стефаник В. Твори. Дніпро, К., 1971.

[Stefanyk V. Tvory. Dnipro, K., 1971.]

[18] Struk D. A Study of Vasyl’ Stefanyk. Ukrainian Academic Press, Littleton, Colorado, 1973.

[19] Біленко Т. Слово як модус і реалія у творчості Василя Стефаника (філософський аспект) В: «Покутська трійця й літературний процес в Украйні кінця ХІХ - початку XX століть: Матеріали наукової конференції. Вимір, Дрогобич, 2001, 33-42.

[Bilenko T. Slovo yak modus i realiia u tvorchosti Vasylia Stefanyka (filosofskyi aspekt) In: Pokutska triitsia y literaturnyi protses v Ukraini kintsia XIX - pochatku XX stolit: Materialy naukovoi konferentsii. Vymir, Drohobych, 2001, 33-42.]

[20] Клиновий Ю. Герої Василя Стефаника в дійсності. В: Кдиновий Ю. Моїм синам, моїм приятелям. Едмонтон-Торонто, 1981, 112-122.

[Klynovyi Yu. Heroi Vasylia Stefanyka v diisnosti. In: Klynovyi Yu. Moim synam, moim pryiateliam. Edmonton-Toronto, 1981, 112-122.] 
Address: Stepan Khorob, Vasyl Stefanyk Precarpathian National University, 57 Shevchenko St., IvanoFrankivsk, 76025 Ukraine.

E-mail: kaf.lit@ukr.net

Received: May 14, 2020; revised: October 26, 2020.

Хороб Степан. Кореляція поетики новели в системі художнього мислення Василя Стефаника. Журнал Прикарпатського університету імені Василя Стефаника, 7 (2) (2020), 15-22.

У статті розгдядається взаємозв'язок художнього мислення і своєрідності поетики в новелістичній творчості класика української літератури Василя Стефаника (1871-1936), 150-річчя якого відзначатиметься у 2021 році. Доведено, що саме модерністський тип авторської ідейно-естетичної свідомості посутньо позначився на особливостях поетики його творів (іх структурній організації, їх образно-смислових концепціях, їх ритмічній будові оповіді, їх драматизмі і зведених до мінімуму описах та динамічних діалогах тощо), що своїми засновками, 3 одного боку, йшла від західноєвропейських традицій, а з іншого боку - продовжувала тенденції розвитку української національної малої прози.

Автор дослідження будує свої спостереження на аналізі новелістичної спадщини Василя Стефаника різних періодів і приходить до аргументованого висновку про те, що його художне мислення (точніше - епічне) мало динамічний характер розвитку, а новелістична поетика корелювалася з ним, збагачуючи стильову палітру його багатожанрової прози (новели, оповідання, образка, поезії в прозі тощо). Задля повноти висвітлення поставленої у статті проблеми дослідник неодноразово звертається до концептуального прочитання творів Василя Стефаника як сучасними, так і закордонними (з української діаспори) стефаникознавцями.

У статті простежено як новеліст з видозміною своєї авторської ідейно-естетичної свідомості постійно вдосконалював систему засобів душезнавства, що безумовно позначалося на внутрішній і зовнішній структурі його творів. Відтак дослідник робить цілком обгрунтований висновок про те, що в художньому мисленні Василя Стефаника органічно сполучалися дві прямо протилежні тенденції віку: з одного боку, прагнення до новелістичної концентрації, а з іншого - неминучість певної деконцентрації при психологічному аналізі. На прикладі багатьох творів письменника виявлено в його епічному мисленні своєрідний закон мистецької компенсації, що ним прозаїк майстерно користувався (насамперед зусібічне зосередження на психічному процесі героя в найінтенсивніший момент пульсації. Тому-то його новели зчаста наближаються до літератури т.зв. "потоку свідомості".

Кдючові слова: контекст, новелістика, поетика, традиції і новаторство, художне мислення. 